\title{
The impact of using proportional representation system on the fragmentation of the party system in Algeria. Applied to the elections of the National People's Assembly (1997-2017)
}

Party system in Algeria

\author{
Ali Mahmoud Mahgoub \\ Foreign Information Sector, Egypt State Information Service, Cairo, Egypt
}

\begin{abstract}
Purpose - The purpose of this study is to examine the impact of using proportional representation system on the fragmentation of the party system in the Algerian political system within the period from 1997 to 2017, in which Algeria has experienced five legislative elections regularly every five years by testing a hypothesis about adopting the proportional representation system on the basis of the closed list during the foregoing legislative elections has obviously influenced the exacerbation of the Algerian party system's fragmentation, compared to other factors.

Design/methodology/approach - The essence of the theoretical framework of this study is to address the effect of the electoral system as an independent variable on the party system as a dependent variable. The starting point for that framework is to reassess the "Duverger's law," which appeared since the early 1950s and has influenced the foregoing relationship, and then to review the literature on a new phase that tried to provide a more accurate mechanism for determining the number of parties and their relative weight, whether in terms of electoral votes or parliamentary seats. This means that researchers began to use a measure called the effective number of parties (ENP) for Laakso and Taagepera since 1979. The study elaborates the general concepts of the electoral system and the party system. It used Laakso, Taagepera index of the "ENP" to measure the phenomenon of fragmentation party during the five legislative elections from 1997 to 2017 in Algeria.

Findings - The results of the study reveal that the proportional representation electoral system - beside other factors - had clear impacts on the fragmentation of the Algerian party system by all standards, whether on the level of the apparent rise in the number of the parties represented in the Algerian parliament from 10 parties in 1997 election to 36 parties in 2017 election or according to the index of Laakso and Taagepera (ENP). The average number of effective number of electoral parties in the five elections was around 7.66 , and the average number of effective number of parliamentary parties in the five elections was around 4.39, which puts Algeria in an advanced degree of the fragmentation of the party system.

Originality/value - This study about the phenomenon of the fragmentation of the party system, which is one of the new subjects in the field of comparative politics - globally and in the Arab world. Hence, the value of this study aims to shed light on this mysterious area of science, the fragmentation of the party system in the Algerian political system during the period from 1997 to 2017.
\end{abstract}

Keywords Party system fragmentation, The electoral system, The party system, The effective number of parties (ENP), The legislative elections in Algeria, Party system fragmentation, The PR system

Paper type Research paper

(C) Ali Mahmoud Mahgoub. Published in Review of Economics and Political Science. Published by Emerald Publishing Limited. This article is published under the Creative Commons Attribution (CC BY 4.0) licence. Anyone may reproduce, distribute, translate and create derivative works of this article (for both commercial and non-commercial purposes), subject to full attribution to the original publication and authors. The full terms of this licence may be seen at http://creativecommons.org/licences/by/4.0/ legalcode

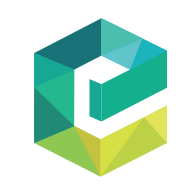

Received 18 January 2020 Revised 9 July 2020 Accepted 10 August 2020 


\section{REPS}

7,4

318

\section{Introduction}

Researchers and scholars in the field of comparative political systems devoted their attention to the phenomenon of the party system's fragmentation recently; however, it is an old phenomenon. Since the 1960s, a number of western political researchers, such as Douglas Ray, Markku Laakso, Rein Taagepera and Arend Lijphart, began to study and analyze the phenomenon. On the other hand, few Arab researchers addressed the foregoing phenomenon; among them were Dr. Mazen Hassan and Dr. Yusri Al-Azbawi (Hassan and Al-Azbawi, 2013), who undertook a brief study on the fragmentation of the Egyptian party system after the January 25th revolution and Inmaculada Szmolka (2010), who provided another study on the fragmentation of the Moroccan party system.

Accordingly, this study tries to shed light on the phenomenon of party system's fragmentation within the Algerian political system from 1997 to 2017, in which Algeria has experienced five regular legislative elections, once every five years.

The study consists of four sections, including the research problem, the importance of the study, the theoretical and conceptual framework and then the case study, which will be applied on the Algerian party system by application on the Algerian case using the Laakso and Taagepera index to measure the effective number of parties (ENP) and the fragmentation of the party system during the five legislative elections from 1997 to 2017, and then the conclusion.

\section{The research problem}

The research problem of that study seeks to answer a key question about the impacts of Algeria's adoption of a proportional representation system during the successive legislative elections from 1997 to 2017 on the fragmentation of its party system.

The study attempts to test a hypothesis about adopting the proportional representation system on the basis of the closed list during the foregoing legislative elections has obviously influenced the exacerbation of the Algerian party system's fragmentation, compared to other factors.

\section{The scientific importance of the study}

Analyzing the impacts of the electoral system on the party system has become increasingly important because few researchers are interested in studying the electoral systems of non-competitive political systems in the Arab region, in general, and Algeria, in particular.

Many researchers argued that the electoral systems of states, that witness electoral irregularities and lack impartiality, are insignificant. Consequently, the current study reconsiders such arguments and goes in a different direction in which electoral systems are already of critical importance in the non-competitive systems than what has been recognized by most academicians and researchers.

The researcher believes that further research is needed in this area to internalize the dynamics and functions of electoral reforms that emerge from time to time in many Arab political systems, in general, and the Algerian system, in particular.

The relationship between adopting the proportional representation on the basis of the closed list and the exacerbation of the Algerian party system's fragmentation is still a controversial case study. The scientific research has not been given enough concern about it. Accordingly, if the hypotheses of the electoral system literature are valid in the Arab context, this would be a proof of their strength, and the difference between the Algerian and Arabic culture would not influence the anticipated relations between the variables of that study. 


\section{The theoretical and conceptual framework}

\subsection{The theoretical framework}

The essence of the theoretical framework of this study is to address the effect of the electoral system as an independent variable on the party system as a dependent variable. The starting point for that framework is to reassess the "Duverger's law," which appeared since the early 1950s and has influenced the foregoing relationship, and then to review the literature on a new phase that tried to provide a more accurate mechanism for determining the number of parties and their relative weight, whether in terms of electoral votes or parliamentary seats. This means that researchers began to use a measure called the ENP for Laakso and Taagepera since 1979.

In 1951, Duverger's explanation of a state's number of parties was fully commensurate with the rational-choice model, while his understanding of the party organization depended on the social and economic moulding of voters. However, the two previous trends, the analysis of Duverger on the numbers of parties was effective enough to continue for a long time. Duverger started with a brief historical explanation for the dualism of parties in the UK and the USA.

Thus, he concluded that the electoral system is of due importance and the single-ballot majority vote is consistent with the dualism of parties. Duverger argued that the numbers of parties could be minimized through the mechanical factor, the underrepresentation of the third party, and the psychological factor, as well as voters' awareness that they may lose their votes if they vote for a third party (Schlesinger, 2006). That analysis was conducted by William Riker who gave it the name of "Duverger's law" in 1982. Since that time, "Duverger's law" has become a core element of studying political parties.

Pippa Norris sought to assess the effects of electoral rules on political conduct, particularly in more than 30 states, and concluded that Duverger's main assumption on multi-electoral systems favor party dualism of parties, whereas proportional representation systems are associated with multi-party system (Schlesinger, 2006).

Christopher D. Raymond concluded that the results of his study proposed that adopting proportional systems caused an exacerbation of the party system's fragmentation that led to the development of the multi-party systems in those states adopted it. That result proved the positive effect of the secular trend on party system's fragmentation, which also led to the development of multi-party systems (Raymond, 2014).

In a study for Pippa Norris conducted in 1997, she touched upon one of Duverger's most famous claims, which is that the plurality rule favors a two-party system while proportional systems lead to multi-party systems. This raises a question of how to count parties, particularly very small ones. In recent years, Lijphart (1994) reconsidered the evidence for this assumption. During the period between 1945 and 1990, Lijphart compared 27 advanced industrialized democracies based on the Laakso and Taagepera measure of the effective number of parliamentary parties (ENPP), which takes into consideration account not only of the number of parties but also the relative size of them. In addition, Lijphart found that the ENPP was 2.0 in plurality systems, 2.8 in majority systems and 3.6 in proportional systems. Within proportional systems, he found that the minimum votes also had an effect on the inclusion of minor parties (Norris, 1997).

Pippa Norris used the same measure (ENPP) to expand the scope of the analysis to cover a wider range of democracies, including developing and developed societies, particularly in that election held in the mid-1990s. The results of that analysis showed that the ENPP was 3.1 in majority systems, 3.9 in mixed or semi-proportional systems and 4.0 in proportional systems. Duverger's law, which ascertained that proportional representation systems are associated with a multi-party system lent greater confirmation for the foregoing analysis (Norris, 1997).

Party system in Algeria 
REPS

7,4

Finally, the study depends on the conclusion of REIN TAAGEPERA and BERNARD GROFMAN in which all attempts to count the number of political parties emerging in democracies was usually based on one of two seemingly incompatible approaches:

(1) The "institutional" approach (e.g. Duverger's law and hypothesis focused on the nature of the electoral system and on the number of seats per district.

(2) The "ideological" approach, which stressed the nature and degree of social cleavages.

TAAGEPERA and GROFMAN tried to synthesizing between the two foregoing approaches through showing that the election system and cleavage type interacts to affect the number of parties. The most striking result is that the ENP is counted by adding "one" to the number of parties. Duverger's hypothesis is replaced by a much more number to predict the ENP (Grofman, 1985). ENP is the measure that the study will rely on to analyze the Algerian case, and it will be examined in more detail in the conceptual framework.

\subsection{The conceptual framework}

This section addresses the concepts of the study, which are party system, party system's fragmentation, the effective number of political parties (ENP), the electoral system and the proportional representation system on the basis of the closed list, as follows:

4.2.1 The party system. Most literature on the party phenomenon focused on studying it in terms of its origin, composition, function, as well as types and classifications of party systems prevalent in the world whether bilateral, pluralistic, polarized or non-polarized, competitive or non-competitive, institutional or non-institutional, etc. Thus, researchers did not develop a precise definition of the party system itself.

In addition, many scholars were keen to distinguish between political parties and party system, the later reflects the interactions between parties existing within a political system while the former is political organizations that aim to gain power, and rule. "Scott Mainwaring" was one of the most eminent scholars who attempted to develop an approach to the definition of a party system, as he defined it as being "a combination of interconnected parts that interact in a typical way to form the complex." After that, "Mainwaring" introduced another definition of the party system as being "the system in which a group of parties interact in typical or systematic ways to formulate that system." The concept of systemic interactions refers to critical rules of how parties compete widely, even if some rules are contentious and subject to change. The idea of a system focuses on the continuity of the components of that system and guarantees a minimum stability of the party competition, and if a severe break in the constituent parts of that system occurs, a different system will replace the former one (Mainwaring, 1998, p. 7).

"Maurice Duverger" defined the party system as "a group of elements: number of parties, their internal structures and their size, as well as the form of alliances between these parties and the opposition model practiced by them within a political system, which are stable over a relatively long period" (Wahab, 2011, p. 138).

The British jurist, "James Price," used the term "party system" to refer to "a system in which political parties as muscles and nerves for bones; they are the formal structures and institutions in a political system" (Slimane, 2013, p. 74).

On the level of Arab literature, the Algerian political professor "Abdelkader Abdulali" developed a definition of the party system as being "a system of interactions that are consisting of opposing and cooperative relations between political parties, which operate within the political arena; this means that a party system represents a sub-system of the political system" (Abdulali, 2008, p. 65). 
4.2.2 The fragmentation of the party system. The Italian researcher "Giovanni Sartori" was the first to address the concept of a fragmented party system when reviewing the different types of party systems; he added a new type of party systems other than those systems with limited pluralism, which consist of three, four or five active parties and those with excessive pluralism, which consist of more than five parties. The later is called a fragmented party system, which is significantly disintegrated, given that including more than one party makes no difference in the pattern of political and party competition. "Sartori" argued that a party system is not a system with a coherent structure (Richard, 2006, p. 57).

In practice, a study on the party system of Ukraine argued that the party system prevailed was fragmented due to the weakness of parties and the instability in their relationship, particularly in the early 1990s (1990-1994); that was linked to the period of building a multi-party system after the unilateral era prevailed in the Soviet era (CENTER, 2017, p. 8).

The study of both "Youssry Aezzbawi" and "Mazen Hassan" that was entitled "The Party Map in Egypt after the Revolution: From the Restricted Pluralism to the Fragmentation of Party System" and published in 2013, was one of the most important Arabic studies that tackled the phenomenon of party system's fragmentation (Hassan, 2013). As well, a research paper conducted by "Inmaculada Szmolka" analyzed the fragmentation of the Moroccan party system and the effect of the electoral system on fragmentation, considering certain elements such as apportioning seats within constituencies, the electoral formula and the electoral barrier. Szmolka highlighted some characteristics of fragmentation, using the Rae's fractionalization index, the ENP and the parties in government coalitions (Szmolka, 2010).

Another study by Dr. "Mazen Hassan," entitled "The Political Effects of the Egyptian Electoral System through Applying to the People's Assembly Elections hold in 2011/2012," sought to highlight the political implications of adopting the parallel mixed system in the election of the Egyptian People's Assembly hold in 2011/2012 according to five main outputs (variables), which are the voter turnout, the level of representation of women, the structure of the party system, the degree of non-relatively and the electoral cost of the parliamentary seat. The key assumption of Hassan's study is that the institutional factor represented in the electoral system is able to influence the foregoing outputs (variables) through empirical tests that show the apparent institutional impact on the degree of party system's fragmentation, but the effect of the institutional factor may decline due to social or cultural factors, particularly in terms of the voter turnout, and the level of representation of women (Hassan, 2013).

In a study of the Algerian researcher "Omar Ben Slimane" entitled "The effect of the electoral system on political parties in Algeria: 1989-2012," the researcher tackled, but just briefly, the fragmentation of the Algerian party system according to the Laakso and Taagepera index in the four legislations in Algeria from 1997 to 2012. The scale appeared in the 1997, 2007 and 2012 elections and did not appear in the 2002 election (Slimane, 2013).

In her $\mathrm{PhD}$ dissertation, "Robin E. Best" referred that documenting a party system's fragmentation requires a precise definition of the size of a party system. She relied on the ENP as a primary measure of the size of a party system. (ENP) indicates the hypothetical equalsized parties that would have the same effect on fractionalization of the party system like the actual parties with varying sizes. For example, if four parties gained 25\% of the legislative seats for each party, and then the (ENP) is exactly four. The use of the (ENP) as the measure of a party system's size allows party vote shares to determine their weights. All parties receiving votes or seats are included in the calculation, although parties that gained very few votes or seats will count much less toward the overall number while larger parties will count

Party system in Algeria 
REPS

7,4

more. Thus, the use of the (ENP) as the measure of a party system's size avoids the problems of alternate measures, such as arbitrary cutoff points for counting parties, by allowing all parties to determine their own degree of relevance. Furthermore, this measure is sensitive to fluctuations in electoral returns, and is able to aptly capture changes in a party system's size over time (Best, 2007).

Finally, "Christopher D. Raymond" is considered one of the fewest scholars who attempted to develop a definition of fragmentation. "Raymond" meant by fragmentation not only the number of parties, but their relative voting strength, as well (Raymond, 2014).

4.2.3 The effective number of parties. The term of "ENP," which takes the acronym (ENP) was developed in late 1970s by "Laakso and Taagepera," and it was known as the Laakso and Taagepera index (Laakso, 1979). After that, many studies focused on analyzing and modifying the concept in addition to analyzing its close relation with the phenomenon of party system's fragmentation because the basic idea of the concept was to measure the fragmentation of the party system in any country using mathematical equations and methods.

According to the Dutch American researcher "Arend Lijphart," the ENP is a concept provided by "Laakso And Taagepera" in 1979, as an attempt to figure out the number of political parties in a country, and, at the same time, to identify the relative weight of these parties in which the relative strength refers to the parties' share of electoral votes (the effective number of electoral parties ENEP) or refers to their share of the seats in the parliament (the ENPP). That procedure is useful, in particular, comparing the effects of electoral systems within different countries. The number of parties becomes equal to the ENP when all parties are equally strong, but in another case the ENP may be less than the actual number of parties. In general, the ENP is a recurrent process for measuring the fragmentation of a party system (Lijphart, 1999, Patterns of Democracy).

Both "Patrick Dumont" and "Jean-François Caulier" argued that the ENP is a standard numerical measurement tool used in the comparative analysis of party systems designed by "Laakso" and "Taagepera" in 1979 (Caulier and Dumont, 2003, p. 2). "Sartori" named that measure as the smart way to count parties within a political system. Some scholars believed that the simplest way to identify the number of parties is to monitor the number of parties represented in parliament; however, some other scholars defined a minimum number of seats in parliament such as $3 \%$, as they figured that parties got this percentage or higher are related to the party system. The two French research studies called the foregoing as "the effective number of relevant parties" (Caulier and Dumont, 2003, p. 3).

The two French researchers, namely, "Patrick Dumont" and "Jean-Francois Caulier," elaborated on clarifying the relationship between the fragmentation of the party system as a phenomenon and measures of the ENP. They argued that the level of competition between political parties is of importance when classifying the party systems. It is said that a fragmented party system is that consists of many elected parties and that can be considered when defining the party system. Dumont and Caulier argued that the number of parties alone does not reflect the nature of the party system; however, the criterion for quantity is still significantly considered when measuring the party system's fragmentation (Caulier, 2011, p. 2).

The ENP developed by "Laakso" and "Taagepera" in 1979 is still the most widely and consistently used index despite some flaws emphasized by researchers (Caulier and Dumont, 2003, p. 3).

The current study adopts the argument developed by "Arend Lijphart" about the "ENP" in which he applied Laakso and Taagepera index to 27 Western democratic countries from 1945-1990. "Lijphart" addressed a theoretical problem found in the literature of comparative 
politics on how to count parties in a party system and, at the same time, considering the relative weight of each party, particularly small ones. "Lijphart" pointed to the British party system, which was usually known to be a bipartisan system, but, in fact, there were more than two parties represented in the House of Commons, which means that third parties were not simply counted (Lijphart, 1994, p. 67):

"Douglas Rae" presented an index based on the percentage of votes obtained by each party in the elections through the following equation " $\mathrm{Fv}=1 / \sum$ vi2" and also based on the proportion of parliamentary seats obtained by each party participating in the elections through another similar equation, which is "Fs $=1 / \sum$ si2."

Regarding the values of fragmentation in the Douglas Rae index, "Dumont" and "Caulier" indicated that the more the result of the later formula for measuring the fragmentation rate of a party system is close to 1 , the more the party system is fragmented. For example, we have five parties; each one has $20 \%$ of the available seats $(0.2 \%)$. The Rae index will reach 0.80 , indicating a highly fragmented party system. All five square proportions of seats should be added and the result should be extracted from 1 . Nevertheless, if a party gains all the seats and gets one percentage, the Rae index will point to zero (the minimum value of the index) and this means that the party system is not fragmented. Therefore, the fragmentation index designed by Rae provides critical information on the number and relative size of parties (Caulier and Dumont, 2003, p. 4).

The next formula clarifies how to calculate (ENP) and the logical link of ENP to Rae index, which can be also calculated through identifying the percentage of votes obtained by the party in the legislative elections and the number of seats obtained by the party in parliament. Consequently, there are two equations to get the ENP of a party system within any country, as follows:

Equation of electoral votes of a specified party:

$$
\mathrm{N}=1 / \sum(\mathrm{vi})^{2}
$$

Equation of the parliamentary seats of a specified party:

$$
\mathrm{N}=1 / \sum(\mathrm{si})^{2}
$$

"Lijphart" argued that the concept of an ENPP provides the same data included by Rae index on the fragmentation of a party system. $(\mathrm{N})$ can be calculated from $(\mathrm{F})$ through the following equation:

$$
\mathrm{N}=\frac{1}{1-\mathrm{F}}
$$

"Lijphart" contended that (ENP) developed by "Laakso" and "Taagepera" and symbolized by $(\mathrm{N})$ accurately determined the number of parties rather than the Rae index symbolized by (F) and developed by Douglas Rae. "Lijphart" gave an example to illustrate the foregoing as follows; in a bi-partisan system in which each party has an equal share of electoral votes or parliamentary seats, the scale $(\mathrm{N})$, which indicates the ENP equals 2 while the scale $(\mathrm{F})$ equals 0.50 . Nevertheless, if one of the two parties became stronger than the other and obtained $70 \%$ and the second party had $30 \%$, the scale $(\mathrm{N})$ will equal 1.72 . That is consistent with the general preliminary ruling that a party system is going to be a single party. In this case, Rae scale $(\mathrm{F})$ equals $t 0.42$. Similarly, a three-party system will have the same proportions in which $(\mathrm{N})$ will equal 3 and (F) will be 0.67 , but if one of these three parties becomes less than the other two parties, $(\mathrm{N})$ will fluctuate between 2 and 3 depending on the relative strength of this third
Party system in Algeria

\footnotetext{
.
} 
REPS

7,4

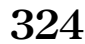

party, while $(\mathrm{F})$ will be between 0.50 and 0.67 according to the example provided by "Lijphart" (Lijphart, 1994, p. 68).

"Lijphart" emphasized on the index of (ENP) in which within each electoral process, the (ENP) can be applied to the share of electoral votes of parties participating in this process, and that is symbolized by (V). In addition, it can be applied to the share of seats in parliament gained by those parties participating in elections and symbolized by (S). Thus, each party participating in an electoral process will gain votes but this does not mean that all parties involved, particularly small, will gain seats in parliament. The whole process is affected by many other factors such as mechanical and psychological factors, as well as proximal and distal factors (Lijphart, 1994, p. 69).

"Lijphart" argued that the mechanical and approximate (proximal) factors influence the process of converting votes into seats in the elections immediately. Here, a question is arisen about to what extent the foregoing is biased against small parties? "Lijphart" referred to the voters, politicians, political activists and financial supporters who are unwilling to waste their voices, energy or money and they will tend to elect large parties. Consequently, such a strategic behavior eliminates the psychological and exclusionary (distal) impacts of electoral systems; the ENEP is affected only by the psychological effects of electoral systems. The ENPP is influenced by expectations (psychological factors) and by actual mechanical factors in the process of converting votes into seats. In other words, the ENEP is likely to be minimized because of psychological factors. However, any reduction in the ENEP in favor of the ENPP will be exclusively due to the impact of mechanical factors (Lijphart, 1994, p. 70).

4.2.4 The electoral system. The definitions of an electoral system are numerous, expanding and narrowing from one researcher to another. Dr. "James Connolly" was one of those who provide a narrow concept of electoral system in Western literature. "Connolly" focused on the electoral formula considerably, and defined the electoral system as "a set of rules to transform the votes cast in elections to the representative assembly seats in accordance with specific formula electoral." Here, he identified the electoral formula to be "the rule that governs the transformation process of votes into seats." Accordingly, "Connolly" figured out that there are different types of electoral formulas, but they can be collected in groups as follows: majority systems in which candidates should obtain a majority of votes to be elected whether absolutely or relatively, proportional representation systems in which parties' candidates are represented in proportion to the votes gained by each party, and mixed systems that combine two of the following systems (Connolly, 2013, p. 5).

Dr. "Abdel Salam Nuer" was one of those who adopted a narrow concept of electoral system in Arabic literature. He defined that concept as "a set of principles, rules and institutions that organize and affect the process of election." In other words, the electoral system refers to a set of procedures by which the votes are transformed into seats in legislative bodies (Nuer, 2003, p. 22).

The majority of Western researchers tended to adopt the wide concept of electoral system. "David M. Farrell" was a pioneer researcher in that field as he differentiated between electoral systems and electoral laws. "Farrell" provided a specific definition for electoral systems; these systems determine the means through which votes are transformed to seats in an election. "Farrell" also argued that an electoral system is "a set of rules that deal with the electoral process itself with regard to how voters vote, the design of the ballot paper, the way of counting votes, determining who is finally win the elections." Electoral laws as a group of rules governing the electoral process as a whole, starting from calling for elections, clarifying the conditions for candidates, electioneering, the voting process and ending with counting votes to determine the outcome of the elections; "Farrell" focused on the rule of determining who has the right to vote whether 
citizens, residents, those above 17 years of age or others. In addition, "Farrell" highlighted the conditions required for candidates such as the collection of signatures of voters in a constituency and the obligation to pay amounts as deposit for the electoral process. $\mathrm{He}$ also addressed the rules related to electioneering whether on radio or on TV or in newspapers or by putting up fliers in public squares or on buses or etc. (Farrell, 2011, pp. 3-4).

"Lijphart," in turn, procedurally provided a definition of the electoral system by changing it into indicators, including the nature of the electoral formula, the size of the constituency, the electoral threshold, the size of parliament, the structure of vote, the unequal division of electoral districts and etc. (Hassan, 2006, pp. 16-17).

Meanwhile, the Algerian researcher "Omar Bin Silmane" adopted the broad definition of the electoral system, which was applied on the Estonian system. "Bin Silmane" argued that designing an electoral system is that process of determining the components of the electoral system based on certain inputs needed to determine the conditions for registering in lists, and the number of parties competing, as well as the components and the authorities of the electoral commission. The foregoing inputs also include identifying the timetable for conducting elections. "Bin Silmane" also contended that designing an electoral system includes determining the type of the electoral system adopted the number and size of electoral constituencies, the number of seats allocated for each constituency, the structure and pattern of the ballot paper and etc. (Slimane, 2013, p. 148).

4.2.5 Proportional representation system. Proportional representation (PR) system is based on a core idea is that each political party provides a list of candidates in each constituency. The voters vote in favor of certain parties, in which each party wins a share of seats of in a constituency, which is commensurate with its share of votes gained. The candidates of parties' lists win according to their serial order within these lists. PR system does not determine the form of the electoral system adopted individually, but the later can be set out through calculating the seats after counting the votes (aceproject.org) (aceproject.org).

Ranking PR formulas has been approached both theoretically and empirically by many scientists as Gallagher and Blondel, Lijphart, Loosemore and Hanby, but agreement is not universal. The most widely accepted ranking is Lijphart's (1986), which considered the Hare and Droop largest remainder (LR) methods to be the most proportional, followed by the Sainte-Lague highest-average (HA) method, followed by Imperiali LR, d'Hondt HA and Imperiali HA (Benoit, 2000).

PR system has many merits, but the most important is justice in representation. They also allow representing various political currents according to electoral power; they are like a machine registration, which encourages to create a strong opposition in parliamentary bodies and to prevent the domination of the majority party over the government. Strong opposition is one of the most important pillars of the parliamentary system in democratic countries and it pushes voters to pay more attention to public affairs (Larkam, 2006, p. 46).

Although PR system also enhances establishing new parties, adopting the multi-lateral system and empowering minority parties and women, it lacked government stability due to the large number of parties that form the government, and the difficulty in candidacy for independent candidates, and the high possibility of extreme parties to have some representation. In addition, one of the most critical drawbacks of PR system is to be a vague and complex system, particularly, as distribution of seats is subject to mathematics, which are difficult for the public to understand (Larkam, 2006, p. 47).

Many researchers addressed the relationship between PR system and party system's fragmentation, such as "Douglas W. Rae" in his book, entitled "The Political Consequences of Electoral Laws," which was issued in 1967. "Rae" analyzed 121 elections in 20 democracies from 1945 to 1964, indicating that PR systems - with variations related to electoral formulas

Party system in Algeria 
REPS

7,4 and district magnitude - were, in general, associated with more fragmented party systems than plurality or majority systems (Quenter, 2000).

\section{The Algerian case}

Since the beginning of political and party pluralism in Algeria in 1989, it experienced six legislative elections; the first one was in December 1991 and resulted in a landslide win for the Islamic Salvation Front and that win led to the intervention of the army to stop the electoral process, and the resignation of president "Chadli Ben Gadid." Consequently, the political system prevailed entered a new bloody conflict continued along an entire decade, which was known as "Red or Bloody Decade".

Meanwhile, Algeria witnessed the other five legislative elections during the period from 1997 to 2019, the study period. The current study attempts to answer the key research question, which is about the impacts of Algeria's adoption of the proportional representation system during the successive legislative elections from 1997 to 2017 on the fragmentation of its party system. Answering this question will be through three sections, as follows.

\subsection{The closed- list proportional representation system}

Since 1997, and according to the outcomes of the seminar on national reconciliation in Algeria, Algeria, in turn, has transformed into a new electoral system. The system adopted was proportional representation that would, at least theoretically, meet two very critical requirements that are central to any electoral system, namely, fairness and stability. An electoral system is a mechanism whereby votes are translated into seats. When votes are not approximately translated into seats, as was demonstrated under the previous twoballot systems adopted in 1990 and 1991 elections, the system is perceived to be unfair. Hence, for a system to be perceived as fair, and indeed legitimate, there should be a clear correlation between the votes won and the seats gained. A stable political system is affected and measured by the number of parties forming the government. Therefore, the Algerian authorities adopted the closed party list electoral system, which put a threshold of $5 \%$ for parties to gain representation in the National Assembly. The electoral system aimed to better reflect the popularity of parties, avoid manufactured majorities and produce a parliament where several parties are represented, according to their share of votes (Bouandel, 2005). Under this system, five legislative elections were held since 1997 until 2017.

Since 2012, People's National Assembly (APN) consisted of 462 seats elected for five years and adopted a closed-list proportional system where political parties and independents can field candidates equivalent to the number of seats allocated for each constituency. The 2016 electoral law allocated at least one constituency for each state, although heavily-populated states could be allowed more districts. In addition to the 48 national districts, there are 4 districts of two seats, which are for Algerians abroad (Morsy, 2017).

The proportional system applied the method of a $5 \%$ threshold. The electoral coefficient is calculated by dividing the number of votes cast on the number of seats allocated for a district. The resulting number is then used as a basis for distributing the seats among lists that pass the threshold, starting with the highest integer to the lowest one, and then from the highest remaining fraction to the lowest one. When linking between two lists or more over the last seat, the list with the youngest candidates wins (Morsy, 2017).

Algeria witnessed, during the period from 1997 till 2019, five legislative elections; all of these elections were based on the PR system but with some differences in the dimensions of 
the electoral system adopted, particularly from one election to another. Some of these elections, such as the 2007 election, witnessed narrowing the participation of political parties existed in the Algerian scene in which the parties' lists required obtaining at least 3\% of the signatures of voters registered in constituencies and these signatures should be distributed to $(50 \%+1)$ at least between the municipalities of the state, without the minimum of $3 \%$ in each municipality (Slimane, 2013, p. 248). Nevertheless, some of these elections, such as the 2012 election held after the Arab Spring Revolutions, paved the way for these parties, in which the condition for existing in more than $(50 \%+1)$ of the Algerian districts was abolished (Slimane, 2013, p. 253).

Moreover, the 2012 law, that promoted women's participation in local and national bodies, established a quota for women at between $20 \%$ and $40 \%$ of the list's candidates, depending on the number of seats allocated to each district. This number raised to $50 \%$ for the seats allocated to Algerians abroad. There was a considerable increase in women parliamentarians from $7.7 \%$ in 2007 to more than $31 \%$ (about 146 seats) in 2012. This made Algeria the only Arab country in which women constitute over $30 \%$ of the parliamentary representatives (Morsy, 2017).

The 2017 election was held exactly one year after adopting the constitutional amendment in 2016, which was the first elections regulated in Algeria under the new constitution, which included a whole chapter on monitoring the elections, and created a supreme independent body for monitoring these elections, which was chaired by a national figure appointed by the president of the republic, particularly after consulting parties and politicians. The supreme independent body was equally formulated from judges who were proposed by the Supreme Judicial Council in addition to independent competencies chosen from the civil society; both were appointed by the president of the republic. That supreme body was responsible for monitoring the local, legislative and presidential elections. Formulating that Independent Electoral Monitoring Commission was a response to the demands of the opposition to achieve a democratic transition after finishing the presidential elections in 2014. Opposition parties aimed to formulate an independent committee of the administration to organize elections and avoid electoral fraud (Ali, 2017).

\subsection{The numerical representation of the parties in the National People's Assembly}

The study will rely on two concepts related to the ENP and they are the ENEP that participate in the successive parliamentary elections and the effective number of the parliamentary parties (ENPP) in which parties were enabled to win seats in parliament even if one seat. Here, "Rae" argued that all parties will not be managed to be actually represented in parliament because this representation depends on the strength of its electoral base and its position of a social conflict. These two concepts were also addressed by the Algerian researcher "Omar Bin Slimane” within his study (Slimane, 2013, p. 205).

The analytical reading of data in Table 1 describes the variation and the discrepancy between the two types, namely, the parties participating in the election and those already representing in the National People's Assembly, which went through the Algerian legislative elections held from 1997 to 2017.

While the proportion of the relationship between the foregoing parties was extremely weak, particularly in the 1997 elections, and amounted to $25 \%$, as the political parties participating in this election were 39 and only 10 parties succeeded in winning the seats and being represented in the parliament. Table 1 shows a relative rise in the following legislative elections in 2002, valued at $39 \%$, as the political parties participating in this election were 23 political parties and only nine parties succeeded in obtaining seats in the parliament. That proportion considerably rose in the 2007 election and surpassed $91 \%$ as the political parties

Party system in Algeria 


\begin{tabular}{|c|c|c|c|c|c|}
\hline \multirow[b]{2}{*}{$\begin{array}{l}\text { REPS } \\
7,4\end{array}$} & & & \multirow{2}{*}{\multicolumn{2}{|c|}{$\begin{array}{l}\text { No. of parties } \\
\text { represented in the } \\
\text { parliament } \\
\text { (ENPP) }\end{array}$}} & \\
\hline & $\begin{array}{l}\text { Elections/party } \\
\text { participation }\end{array}$ & $\begin{array}{l}\text { No. of participating } \\
\text { parties (ENEP) }\end{array}$ & & & $\begin{array}{c}\text { The ratio } \\
\text { between them } \\
(\%)\end{array}$ \\
\hline \multirow[b]{3}{*}{328} & The 1997 election & 39 & - & 10 & 25 \\
\hline & The 2 & 23 & $2^{(a)}$ & 9 & 39 \\
\hline & & 24 & $3\left(^{b}\right)$ & 22 & \\
\hline & The 2012 election & 56 & $1\left({ }^{\prime}\right)$ & 27 & 50 \\
\hline & The 2017 election & 60 & $2\left({ }^{d}\right)$ & 36 & 60 \\
\hline & \multirow{6}{*}{\multicolumn{5}{|c|}{$\begin{array}{l}\text { Notes: Data included within the foregoing table was prepared by the researcher depending on many previous } \\
\text { studies of Algerian researchers such as: Larkam (2006), Slimane (2013), Ali ( } 2017) \text {. } \\
\text { a The two boycotting parties for this election were the FFS Socialist Forces Front and RCD National Rally for } \\
\text { Culture and Democracy. } \\
\text { bThe boycottingparties were: the Socialist Forces Front, the movement of social democratic party (Communist) } \\
\text { Socialistworkers Party (Trotskyite). } \\
{ }^{c} \text { The boycotting party for this election was the Rally for Culture and Democracy (RCD). } \\
\text { d The two boycotting parties for this election were the party of new generation(GeelGadid), led by SufianDjilali } \\
\text { and the Party of the vanguard of freedoms (TAL, A ALHORRYAT) under the leadership of Ali Ben Flees }\end{array}$}} \\
\hline & & & & & \\
\hline The numerical & & & & & \\
\hline & & & & & \\
\hline $\begin{array}{l}\text { sentation in } \\
\text { ian legislative }\end{array}$ & & & & & \\
\hline & & & & & \\
\hline
\end{tabular}

participating in this election was 24 political parties and 22 parties succeeded in obtaining seats in the parliament. However, the proportion of the relationship between the foregoing parties significantly declined in the 2012 election to reach about $50 \%$, as the political parties participating in this election were 56 political parties and about 27 party succeeded in obtaining seats in the parliament and managed to have parliamentary representation, including three parties belonged to one bloc and known as "The Green Algeria," which consisted of HMS (Movement of Society for Peace), ENHDA (Movement of Renaissance) and ISLAH (Reformation Movement).

Furthermore, the proportion of the relationship between the foregoing parties rose in the 2017 election of the year to be amounted to $60 \%$, as the political parties participating in this election were 60 political parties and about 36 parties and coalitions succeeded in obtaining seats within the parliament. There were two parties in the collation of Movement of Society for Peace (HMS) and the Change Front, and three parties in the Union for Renaissance and justice and construction, which included the Movement of Renaissance, the Front of Justice and Development and the Movement of National Building and five parties in the coalition of Conquest (Fatah), which included the National Algerian Party, the National Free Party, the Movement of the National Liberal, Light Algerian Party (ALNOOR) and Youth Democratic Party (Alshabaab).

Through the five legislative elections from 1997 to 2017, it is possible to notice a steady increase in the number of parties represented in the Algerian parliament (APN), except the 2012 election. The number of these parties rose from 22 parties in the 2007 election to 27 parties in the 2012 election, and then to 36 parties in the 2017 elections. This is considered as an apparent numerical indicator on the case of fragmentation of the Algerian party system in light of the continued application of the closed-list proportional representation system, particularly when focusing on the figures of the seats obtained by several parties represented in these elections, and the parties that got only one seat in each electoral process, which were two parties of 10 parties at a percentage of $20 \%$ in the 1997 election.

The number of parties represented in the APN in 2002 was 3 of 9 parties and amounted to $30 \%$ while their number reached, in the 2007 election of 2007, 3 of 21 parties and valued at $15 \%$. In addition, their number was valued at four of 27 parties and amounted to $15 \%$ in the 
2012 election. In the 2017 election, their number was about 14 of 36 parties winning the election at a ratio of $39 \%$.

In other words, when the Legislative Council had about half of the parties represented by only one member of 462 members representing the total number of members of the Algerian Legislative Council; this can be considered as an indicator of the fragmentation of the party system in Algeria.

An Algerian study clarified that if the PR system allows the presence of minorities and truly reflects the public opinion, this does not necessarily mean fairness and idealism. Although the various positive aspects of the model adopted in Algeria, it magnifies the representation of large parties, even relatively because they took advantage of the votes of parties that did not meet the required ratio, which does not enter in the electoral threshold account ( $5 \%$ of votes), especially, as the system adopted the LR rule. It followed the results of the 1997 and 2002 elections confirmed the benefit of the large parties of the votes of small parties that were not calculated in the process of distribution of seats (Larkam, 2006, p. 112).

The greatest beneficiary of the approved electoral system was always the large parties. The National Democratic Party (RND) won $40.79 \%$ of the seats of the National People's Assembly in the 1997 election, in return for obtaining 33.66\% of votes. The National Liberation Front (FLN) won $51.16 \%$ of the seats of the National People's Assembly in the 2002 election, in return for $36.8 \%$ of votes at the national level. That rule continued to appear in the next legislative elections; in the 2007 election, the (FLN) won with $35 \%$ of the National People's Assembly seats in return for $23 \%$ of votes at the national level. The same case occurred in the 2012 election, where the (FLN) won $48 \%$ of the National People's Assembly seats in return for $21 \%$ of votes at the national level. Accordingly, there was not much difference in the last election held in 2017, where the (FLN) won $35 \%$ of the National People's Assembly seats in exchange for $28 \%$ of votes at the national level (Slimane, 2013; Ali, 2017).

\subsection{The effective number of parties according to the index of the Laakso and Taagepera}

Before going into the details of this point, it is worth noting that the study used the statistical model (Microsoft Excel) obtained by the researcher from Dr. Mazen Hassan, the Department of Political Science at the Faculty of Economics at Cairo University. The following Table 2 shows the results of a virtual 5-party system; each party has a certain percentage of seats in a legislative council that contains 100 seats, and the ENP - according to the formula presented by Laakso, Taagepera index is the sum of their square percentages and then dividing one on the result.

Consequently, the ENP in this hypothetical party system according to the equation: $1 / \sum(\mathrm{si})^{2}=1 / 0.215=4.65$. An output, which is far from 1 , indicating the fragmentation of party system. However, if we assume that Party A, as a dominant party, gets 60 seats and the

\begin{tabular}{lccc}
\hline The party & Parliamentary seats & The ratio & The proportion of seats squared \\
\hline Party A & 30 & 0.3 & 0.09 \\
Party B & 20 & 0.2 & 0.04 \\
Party C & 20 & 0.2 & 0.04 \\
Party D & 15 & 0.15 & 0.0225 \\
Party E & 15 & 0.15 & 0.0225 \\
Total & 100 & 1 & 0.215
\end{tabular}

Party system in Algeria

329 
REPS

7,4

330

rest of the four parties win $10 \%$ of the seats, the ENP according to this equation will become 2.5. An output that is close to 1 , and thus, becomes more focused and less fragmented than its predecessor.

By calculating the rate of fragmentation of party system according to the two indicators (ENEP) and (ENPP) and the comparison between them to show to what extent of the application of the closed-list proportional representation system and using the LR method when converting electoral votes into parliamentary seats, contributed in making further fragmentation in the party system of Algeria after each electoral process and according to Table 3. The study concluded with the following results:

- The average measure of the ENPP during the five Algerian legislative elections came to 4.39 putting Algeria in an advanced degree of the state of the fragmentation party system according to Laakso and Taagepera index for parliamentary seats, although the rate varied from one election to another, where it stood below in 2002 around 3.27, while it reached the maximum in 2007 around 5.49. It also appeared high in the last legislative elections in 2017 by nearly 5.38 .

- The average measure of the ENEP during the five Algerian legislative elections came to 7.66 placing Algeria in an advanced degree of the fragmentation of the party system according to Laakso and Taagepera index for electoral votes, although the rate varied from one to another, where it was low in the 2002 election around 3.36, while the highest was in 2012 election around 12.44, also it appeared high in the last legislative elections in 2017 around 8.19.

- That there was always an increase in the fragmentation of party system rate according to Laakso and Taagepera index in the ENEP than the ENPP, both on the overall average of the five legislative elections, the level of this increase was estimated, according to Table 3 , by 3.27 on the level of each legislative election, but this difference was low in the elections of 2002 that reached around 0.09 , but it mounted to the maximum in 2012 to around 8.73 .

\section{Conclusion}

From the above, it seems that the electoral system applied in Algeria since 1997 till 2017, which is based on the closed-list proportional representation system with the LR method and with a $5 \%$ threshold, contains a number of positive points relevant to the process of

Table 3.

The rate of fragmentation in the Algerian party system

\begin{tabular}{lccr}
\hline & $\begin{array}{c}\text { The rate of fragmentation } \\
\text { according to the electoral } \\
\text { votes equation } \\
\text { (ENEP) }\end{array}$ & $\begin{array}{c}\text { The rate of fragmentation } \\
\text { according to the equation } \\
\text { of parliamentary seats } \\
\text { ENPP) }\end{array}$ & Notes \\
\hline The 1997 election & 4.59 & 4.10 & +0.49 \\
The 2002 election & 3.36 & 3.27 & +0.09 \\
The 2007 election & 9.73 & 5.49 & +4.24 \\
The 2012 election & 12.44 & 3.71 & +8.73 \\
The 2017 election & 8.19 & 5.38 & +2.81 \\
Average & 7.66 & 4.39 & +3.27 \\
Note: Data was Prepared and Adapted by the researcher & & \\
\hline
\end{tabular}


democratic transformation, including the success of the implementation of the legislative elections regularly every five years over 20 years without an interruption as happened in early 1990s of the past century, allowing the representation of the small parties in all successive electoral processes, and permitting a steady increase in the number of parties in the parliament from one election to another.

However, this electoral system - besides other factors - had negative impacts on the successive Algerian electoral experience such as the increasing degree of fragmentation of the Algerian party system by all standards, whether on the level of the numerical representation of the parties in APN as an apparent rise for the parties represented in the APN in the consecutive elections from 10 parties in 1997 election to 36 parties in 2017 election or on the level of Laakso and Taagepera index for the ENP. The first indicator ENEP averaged in the elections five was around 7.66 and the measure of the second indicator ENPP in the five elections was around 4.39, which places Algeria in an advanced degree of the fragmentation party system (the pattern of pluralism party systems, with the presence of two parties dominant, index retail about 4.41 according to the classification made by the scientist of politics Alan Siaroff for party systems, which focuses on the relative size and strength of the votes of the parties obtained more than $3 \%$ in the election.

From the foregoing, it seems that there is a suitable degree of reliability of the hypothesis presented by the study about the existence of a positive relationship between Algeria's system of proportional representation in the closed list, and the high degree of fragmentation in the party system according to the index of Laakso and Taagepera (ENP) during the period 1997-2017. Therefore, it is clear that the Algerian case corresponded to the general theoretical context of the literature presented in this regard about the increasing degree of fragmentation in the party system in light of the use of the PR system. Here the paper proposes to do more in future research on the phenomenon of fragmentation of party systems at the Arab and African levels, as follows:

- Doing more comparative studies among Arab and African countries that follow the system of proportional representation by using the effective party number (ENP), and comparing the extent of their impact on their party systems, and whether or not they effected on the phenomenon of party system fragmentation? Especially, as there are several Arab and African countries that use PR system, including Tunisia, Morocco, Jordan, Iraq, Palestine, South Africa, Namibia, Cameroon, Guinea and Egypt in some periods.

- preparing more comprehensive and comparative studies on the phenomenon of fragmentation of the party system in the Arab and African countries in general, whether those that use the majority, proportional or even mixed electoral systems, by using the effective party number (ENP) of Laakso and Taagepera. This is similar to a lot of studies carried out by western researchers in Western democracies on this phenomenon.

\section{References}

Ali, L.B. (2017), "Legislative elections in Algeria, may 4, 2017: an analytical study", from the Arab Democratic Center, available at: https://democraticac.de/?p=485932017 (accessed 7 January 2019)

Benoit, K. (2000), "Which electoral formula is the most proportional? A new look with new evidence", Political Analysis, Vol. 8 No. 4, pp. 381-388.

Best, R.E. (2007), "Political parties, voters, and institutions:an examination of party system fragmentation", Advanced Democracies, 1950-2005, Binghamton University, New York, NY. 
REPS

7,4

332

Bouandel, Y. (2005), "Reforming the Algerian electoral system", The Journal of Modern African Studies, Vol. 43 No. 3, pp. 393-415.

Caulier, J.F. (2011), "The Interpretation of the Laakso-Taagepera Effective Number of Parties", Documents de Travail du Center d'Economie de la Sorbonne, Paris.

Caulier, J.F. and Dumont, P. (2003), "The 'EFFECTIVE NUMBER OF RELEVANT PARTIES': how voting power improves Laakso-Taagepera's index".

Connolly, J. (2013), "Glossary of electoral systems", Paper presented to the workshop was held with members of the Commission amending the Egyptian Constitution, The Arab Forum for Alternatives Studies Foundation, Cairo.

Farrell, D.M. (2011), Electoral Systems: A Comparative Introduction, Palgrave, London and New York, NY.

Grofman, R.T. (1985), "Rethinking Duverger's law: predicting the effective number of parties in plurality and PR systems - parties minus issues", European Journal of Political Research, Vol. 13 No. 4, pp. 341-352.

Hassan, M. (2006), "The impact of the electoral system on the party system: case study German", Master Degree, Faculty of Economics and Science Political, Cairo University, Cairo.

Hassan, D.M. (2013), "The political effects of the Egyptian electoral system applied to the 2011/2012 people's assembly elections", Democratic Transformation Series, Al-Mahrousa Center for Publishing, Press Services and Information, Cairo.

Hassan, D. and Al-Azbawi, Y. (2013), "Partisan map in Egypt after the revolution: from constrained pluralism to partisan fragmentation", Strategic Pamphlets, Al-Ahram Center for Political and Strategic Studies, Cairo.

Laakso, M. (1979), "The 'effective' number of parties: 'a measure with application to west Europe”, Comparative Political Studies, Vol. 12 No. 1, pp. 3-27.

Larkam, R. (2006), "Electoral systems and their impact on the political parties in Algeria", Master Thesis, Faculty of Law, Mentouri University, Constantine, Algeria.

Lijphart, A. (1994), Electoral Systems and Party Systems: A Study of Twenty-Seven Democracies, 1945-1990, Oxford University Press, New York, NY.

Lijphart, A. (1999), Patterns of Democracy, New Haven/Yale UP, London.

Mainwaring, S. (1998), "RETHINKING PARTY SYSTEMS THEORY IN the THIRD WAVE OF DEMOCRATIZATION the importance of party system institutionalization”, Working Paper \#260, The Kellogg Institute.

Morsy, A. (2017), "An overview of Algeria's upcoming elections, an analytical study", available at: https://carnegieendowment.org/sada/68160 and https://carnegieendowment.org/?lang=en (accessed 18 May 2020).

Norris, P. (1997), "Choosing electoral systems: proportional, majoritarian and mixed systems", International Political Science Review, Vol. 18 No. 3, pp. 297-312.

Nuer, D.A. (2003), "The political dimensions of the development of the electoral system in Egypt. D. A.-M.)", Electoral systems between Egypt and the world, The Faculty of Economics and Political Science, Cairo University.

Quenter, L.K. (2000), "Electoral systems, party system fragmentation and government".

Raymond, C.D. (2014), "The effect of the secret ballot on party system fragmentation: a test of three competing arguments", Politics, Vol. 34 No. 4, pp. 378-390.

Richard, S.K.W.J. (2006), Handbook of Party Politics, SAGE Publications.

Schlesinger, J.A. (2006), "Maurice Duverger and the study of political parties", French Politics, Vol. 4 No. 1, pp. 58-68.

Slimane, O.B. (2013), "The effects of the electoral system on parties in Algeria 2012-1989", Master Thesis, 2013- Saida - Algeria Department of Political Science and International Relations, Faculty of Law and Political Science, University of Dr. Tahir Moula. 
Szmolka, I. (2010), "Party system fragmentation in Morocco", The Journal of North African Studies, Vol. 15 No. 1, pp. 13-37.

Wahab, A.M. (2011), The Electoral System in Algeria. Approach about the Political Participation and

Competition, Dar Ermaah for publication and distribution, Constantine.

\section{Corresponding author}

Ali Mahmoud Mahgoub can be contacted at: aly4m@yahoo.com 